\title{
Use of Secondary Slags in Completely Recyclable Concrete
}

\author{
Mieke De Schepper ${ }^{1}$; Pieter Verlé ${ }^{2}$; Isabel Van Driessche ${ }^{3}$; and Nele De Belie ${ }^{4}$
}

\begin{abstract}
A completely recyclable concrete (CRC) is designed to have a chemical composition equivalent to the one of general raw materials for cement production. By doing so, this CRC can be used at the end of its service life in the cement clinkering process without need for ingredient adjustments, and with improvement of the resource efficiency of cement and concrete production. Copper slag is interesting as an iron source for the production of such a CRC and can be added to concrete, either as alternative binder or as aggregate. By isothermal calorimetry and compressive strength tests it was found that the addition of copper slag as cement replacement is of minor interest. But a study toward the compressive strength and durability of concrete with copper slag as aggregate replacement had promising results. The performance of these concretes was comparable with or even better than the reference concrete, regarding strength and most durability aspects such as porosity and permeability, and resistance against carbonation and chloride ingress. Only the resistance to freezethaw attack with deicing agents was inferior. DOI: 10.1061/(ASCE)MT.1943-5533.0001133. (C) 2014 American Society of Civil Engineers.
\end{abstract}

Author keywords: Concrete; Recycling; Slag; Compressive strength; Durability.

\section{Introduction}

In today's society, concrete is a popular building material: it is strong, gives flexibility in design, and comes with a relatively low cost. However, like all materials, it also comes with an environmental cost. About $42 \%$ (Kogel et al. 2006) of the 15 billion tons (Langer et al. 2004) of aggregates produced each year are used in concrete, of which only $8 \%$ are recycled aggregates (Arab 2006). This use of enormous amounts of natural raw materials is the first environmental problem of the concrete industry. Indeed, at the end of a concrete's life cycle, there is the waste production: $12-21 \%$ of the total waste generated in the European Union is concrete demolition waste (De Belie and Robeyst 2007; C. Fischer and M. Werge, "EU as a recycling society," ETC/SCP working paper 2/2009). These numbers are the motivation for many researchers to work toward a more sustainable construction by resource efficiency and recycling.

To optimize product-recycling opportunities, the Cradle-toCradle (C2C) concept was developed (McDonough and Braungart 2002). In C2C production, all material inputs and outputs are either seen as biological nutrients or as technical resources. Biological

${ }^{1} \mathrm{Ph} . \mathrm{D}$. Candidate, Magnel Laboratory for Concrete Research, Ghent Univ., Technologiepark Zwijnaarde 904, 9052 Ghent, Belgium (corresponding author). E-mail: midschep.deschepper@ugent.be

${ }^{2}$ Engineer, Master of Science in Civil Engineering, Magnel Laboratory for Concrete Research, Ghent Univ., Technologiepark Zwijnaarde 904, 9052 Ghent, Belgium.

${ }^{3}$ Professor, Sol-gel Centre for Research on Inorganic Powders and Thin films Synthesis (SCRiPTS), Ghent Univ., Krijgslaan 281- S3, 9000 Ghent, Belgium.

${ }^{4}$ Professor, Magnel Laboratory for Concrete Research, Ghent Univ., Technologiepark Zwijnaarde 904, 9052 Ghent, Belgium. E-mail: nele .debelie@ugent.be

Note. This manuscript was submitted on January 27, 2014; approved on May 21, 2014; published online on August 11, 2014. Discussion period open until January 11, 2015; separate discussions must be submitted for individual papers. This paper is part of the Journal of Materials in Civil Engineering, (C) ASCE, ISSN 0899-1561/04014177(9)/\$25.00. nutrients can be composted or consumed whereas technical resources can be recycled or reused without loss of quality.

Applying this idea to the production of concrete, a completely recyclable concrete (CRC) was designed (De Schepper et al. 2013; Tamura et al. 2004). In order to make CRC a valuable technical resource for cement production, without need for ingredient adjustments, the concrete mixture should be chemically equivalent to a traditional cement raw meal. The primary ingredient for CRC is limestone aggregate as a source for $\mathrm{CaO}$, the main ingredient for Portland cement production. Besides natural raw materials, such as porphyry aggregate $\left(\mathrm{SiO}_{2}\right.$ and $\mathrm{Al}_{2} \mathrm{O}_{3}$ source), industrial byproducts like fly ash $\left(\mathrm{SiO}_{2}\right.$ and $\mathrm{Al}_{2} \mathrm{O}_{3}$ source), and copper slag $\left(\mathrm{Fe}_{2} \mathrm{O}_{3}\right.$ source $)$ are preferably used for CRC production. The hydration of CRC cement was found comparable with the one of Ordinary Portland Cement (De Schepper et al. 2014).

Copper slag is a by-product obtained during matte smelting and refining of copper. Today, common management options are recycling, recovering of metal and production of value-added products (e.g., abrasive tools, roofing granules, cutting tools, tiles, glass, road-base construction, rail-road ballast, and asphalt pavements; Shi et al. 2008). Still, huge amounts are disposed in dumps or stockpiles. One of the greatest potential applications is in cement and concrete (Shi et al. 2008). In cement production, it can be used as an iron adjusting material or as partial cement replacement (Al-Jabri et al. 2006; Goñi et al. 1994; Gorai et al. 2003; Najimi et al. 2011; Shi et al. 2008; Taha et al. 2004, 2007; Tixier et al. 1997; Zain et al. 2004). Regarding the latter, a major concern is the leaching of heavy metals; however, studies have shown that this is within regulatory limits. Copper slags can also be used as fine and coarse aggregates in concrete production (Al-Jabri et al. 2009a, b, 2011; Gorai et al. 2003; Khanzadi and Behnood 2009; Shi et al. 2008; Thomas et al. 2012; Wu et al. 2010a, b). The density of this copper slag is higher compared with natural aggregates and varies with the $\mathrm{Fe}_{2} \mathrm{O}_{3}$ content between 3.16 and $3.87 \mathrm{~g} / \mathrm{cm}^{3}$ according to Shi et al. (2008). Furthermore the water absorption is very low [0.15-0.55\% according to Shi et al. (2008)] and also the glass-like smooth surface has implications toward the design of concrete mixtures with copper slag. Copper slag also has, however, favorable mechanical properties such as excellent 
soundness, good abrasion resistance, and good stability (Shi et al. 2008).

This paper focuses on the use of copper slag in CRC production. Because of its lower melting point compared to iron ore, a lower calcination temperature within the cement manufacturing process should be feasible (Shi et al. 2008). This creates additional benefits for the environment: a lower energy consumption and reduced $\mathrm{CO}_{2}$ emissions, which makes this waste product even more interesting to be used in CRC. The question remains to how this copper slag is preferably used in CRC. The effect of partial cement replacement by copper slag was studied on cement pastes and mortars. The influence of replacing aggregates by copper slag was studied for mortars and concrete.

\section{Experimental Procedure}

\section{Materials}

The copper slag used in this research is a secondary slag from a Belgian copper, lead, tin, and nickel producer who uses waste products (e.g., old copper wires, dust from the tin production, old televisions and computers, and radiators from cars) as raw materials. On the one hand, a quickly cooled granulated copper slag (QCS) was used for the replacement of the fine aggregates (= sand) in concrete and as a material for cement replacement. A slowly cooled broken copper slag (SCS) was utilized to replace the coarse aggregates. Before using the copper slag as a substitution for cement, QCS was milled 3 times during $4 \mathrm{~min}$ at $300 \mathrm{rpm}$ in a planetary ball mill (mQCS). As a cementitious binder, a CEM I $52.5 \mathrm{~N}$ was used throughout all experiments. An overview of the chemical and mineralogical composition of the cement and copper slag is given in Tables 1 and 2. In Table 2 and Fig. 1, it is seen that, as expected, the quickly cooled granulated copper slag QCS has a higher other amorphous fraction in comparison with the slowly cooled broken copper slag SCS.

The effect of using copper slag as cement replacement was tested on cement pastes (isothermal calorimetry) and mortars (compressive strength). Cement pastes were produced with an increasing copper slag content from 0 to $60 \mathrm{wt} \%$ in steps of $10 \mathrm{wt} \%$. For each paste $10 \mathrm{~g}$ of powder ( $\mathrm{g}$ mQCS with (10-n) g CEM I $52.5 \mathrm{~N}$ ) was mixed with $4 \mathrm{~g}$ of water. The reference composition of the mortars was a standard mortar 6:2:1 (sand:cement:water), for which the copper slag content replacing the cement was increasing in steps

Table 1. Chemical Composition (wt\%) of the Used Copper Slag and Cement (By XRF Analysis)

\begin{tabular}{lrrc}
\hline Oxide & QCS & \multicolumn{1}{c}{ SCS } & CEM I 52.5 N \\
\hline $\mathrm{CaO}$ & 7.09 & 5.18 & 63.12 \\
$\mathrm{SiO}_{2}$ & 25.87 & 29.33 & 18.73 \\
$\mathrm{Al}_{2} \mathrm{O}_{3}$ & 5.92 & 3.23 & 4.94 \\
$\mathrm{Fe}_{2} \mathrm{O}_{3}$ & 45.45 & 50.72 & 3.99 \\
$\mathrm{MgO}$ & 0.81 & 0.47 & 1.02 \\
$\mathrm{Na}_{2} \mathrm{O}$ & 0.80 & 1.99 & 0.41 \\
$\mathrm{~K}_{2} \mathrm{O}$ & 0.19 & - & 0.77 \\
$\mathrm{SO}_{3}$ & 0.37 & 0.24 & 3.07 \\
$\mathrm{P}_{2} \mathrm{O}_{5}$ & 0.82 & 0.41 & - \\
$\mathrm{TiO}_{2}$ & 0.31 & 0.10 & - \\
$\mathrm{ZnO}_{\mathrm{MnO}}$ & 8.8 & 5.43 & - \\
$\mathrm{Cr} \mathrm{O}_{3}$ & 0.74 & 0.41 & - \\
$\mathrm{CuO}$ & 0.73 & 0.36 & - \\
$\mathrm{PbO}$ & 0.35 & - & - \\
\hline
\end{tabular}

of $20 \mathrm{wt} \%$ from 0 to $60 \mathrm{wt} \%$. A CEN sand in accordance with NBN EN 196-1 (NBN 2005) was used to produce these mortars.

For evaluation of the aggregate replacement by copper slag, mortars (for compressive strength tests) and concrete (for compressive strength and durability evaluation) were made. Because of the higher density of copper slag compared with the one of natural aggregates, the replacement levels are volume-based, and the density of the concrete will increase. The copper slag used in this study had a density of $2.99 \mathrm{~g} / \mathrm{cm}^{3}$. Standard mortars were produced, and the sand was replaced by QCS from 0 to $100 \mathrm{vol} \%$ in steps of $20 \mathrm{vol} \%$. Based on these results, the replacement levels for the concrete were fixed, namely 20 and $40 \mathrm{vol} \%$ of the total aggregates volume. On the one hand, the fine aggregates were replaced by QCS (QCS-20 and QCS-40). On the other hand, the coarse aggregates were substituted by SCS (SCS-20 and SCS-40). An overview of the concrete mixtures is given in Table 3. The particle size distribution of most raw materials is given in Fig. 2. All mortar and concrete specimens were stored in a climate chamber at $20 \pm 2{ }^{\circ} \mathrm{C}$ and $\mathrm{RH}>95 \%$ for 28 days before testing, unless specified otherwise.

Table 2. Mineralogical Composition (wt\%) of the Used Copper Slag and Cement (By XRD Analysis)

\begin{tabular}{lccc}
\hline Mineral & QCS & SCS & CEM I 52.5 N \\
\hline Alite & - & - & 53.6 \\
Belite & - & - & 17.0 \\
Ferrite & - & - & 11.2 \\
Aluminate & - & - & 6.2 \\
Gypsum & - & - & 0.8 \\
Bassanite & - & - & 0.9 \\
Anhydrite & - & - & 2.1 \\
Aphthitalite & - & - & 0.3 \\
Arcanite & - & - & 0.5 \\
Syngenite & - & 0.6 & 0.7 \\
Zincite & 0.4 & 0.8 & - \\
Hematite & - & 0.4 & - \\
Wuestite & 1.6 & 45.5 & - \\
Fayalite & 4.1 & 3.9 & - \\
Hercynite & 4.0 & 48.8 & - \\
Other & 89.9 & & 6.8 \\
\hline
\end{tabular}

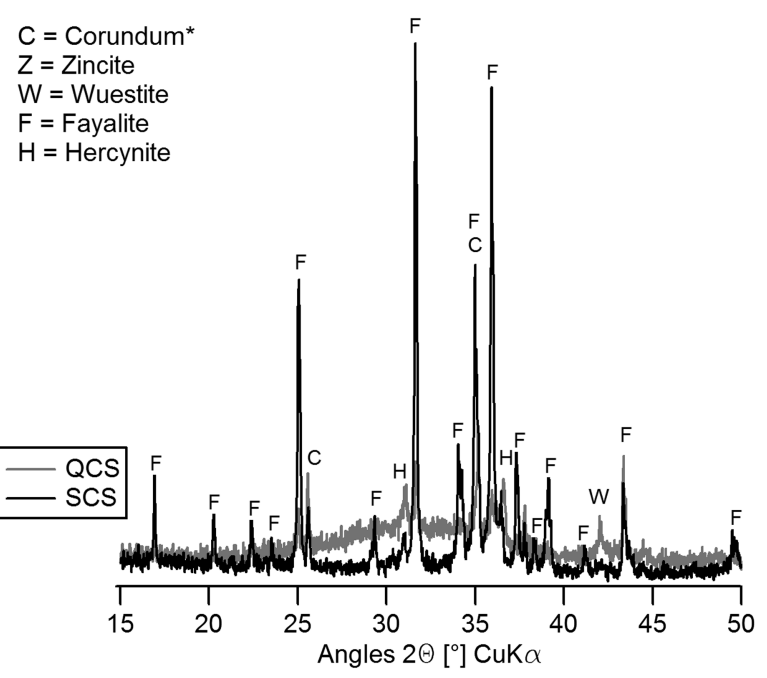

Fig. 1. Observed XRD patterns of QCS and SCS between 15 and $50^{\circ}$ $2 \theta$; the large bump in the $20-40^{\circ} 2 \theta$ range in case of QCS results from the scatter from the amorphous fraction (Corundum was added as internal standard for quantification of the other phases) 
Table 3. Produced Concrete Compositions

\begin{tabular}{lccccc}
\hline Concrete raw material & CS-0 & QCS-20 & QCS-40 & SCS-20 & SCS-40 \\
\hline River sand 0/4 $\left(\mathrm{kg} / \mathrm{m}^{3}\right)$ & 762.3 & 383.2 & 0 & 786.3 & 836.6 \\
QCS $\left(\mathrm{kg} / \mathrm{m}^{3}\right)$ & - & 403.1 & 848.3 & - & - \\
SCS $\left(\mathrm{kg} / \mathrm{m}^{3}\right)$ & - & - & - & 403.1 & 857.7 \\
Gravel $2 / 8\left(\mathrm{~kg} / \mathrm{m}^{3}\right)$ & 449.9 & 464.0 & 488.3 & 311.9 & 169.9 \\
Gravel $8 / 16\left(\mathrm{~kg} / \mathrm{m}^{3}\right)$ & 741.7 & 765.0 & 805.0 & 514.1 & 280.1 \\
CEM I 52.5 N $\left(\mathrm{kg} / \mathrm{m}^{3}\right)$ & 340 & 340 & 340 & 340 & 340 \\
Water $\left(\mathrm{kg} / \mathrm{m}^{3}\right)$ & 153 & 153 & 153 & 153 & 153 \\
Superplasticizer & 5 & 2 & 2 & 2 & 2 \\
(ml $/ \mathrm{kg}$ binder) & & & & & \\
\hline
\end{tabular}

\section{Methods}

\section{Isothermal Calorimetry of Cement Pastes}

The tested powder (cement and copper slag) was mounted in a glass vial. After the addition of water, the cement pastes were mixed manually for $20 \mathrm{~s}$ in the glass vial. Subsequently, it was immediately placed in an isothermal calorimeter (TAM AIR) at $20^{\circ} \mathrm{C}$ to measure the hydration heat during the first 7 days of hydration. The measurement started within $30 \mathrm{~s}$ after addition of water. Because mixing occurred outside the calorimeter, the first hydration peak could not be registered entirely. Because this peak only amounts to a few percent of the total heat liberated (De Schutter 1999), it will not be considered in further analysis. To avoid significant differences between the paste and the isothermal environment, the components were kept at a temperature close to the measurement temperature before mixing.

\section{Compressive Strength of Mortars and Concrete}

Compressive strength tests on mortar specimens $(160 \times 40 \times$ $40 \mathrm{~mm}^{3}$ ) were performed according to NBN EN 196-1 (NBN $2005)$ at the age of 7 and 28 days. The concrete cubes $(150 \times 150 \times$ $150 \mathrm{~mm}^{3}$ ) were tested for their compressive strength at the age of 2 , 7, 28, and 84 days according to NBN EN 12390-1 (NBN 2001a).

\section{Durability of Concrete}

Open Porosity. The open porosity of the concrete specimens (drilled cores $d=100 \mathrm{~mm} h=50 \mathrm{~mm}$ ) was determined using the vacuum absorption test described in NBN B 05-201 (NBN 1976). After drying and weighing the samples $\left(w_{d}-\mathrm{kg}\right)$, they were put under vacuum (2.7 Pa) for $3 \mathrm{~h}$. Subsequently, the tank was filled with water, and the samples were stored under water for $24 \mathrm{~h}$.
Finally the mass of the specimens was determined in air $\left(w_{a}-\mathrm{kg}\right)$ and water $\left(w_{w}-\mathrm{kg}\right)$. The porosity $(\varphi-$ vol $\%)$ of the sample could then be determined by calculating the volume of the pores filled with water

$$
\varphi=\frac{V_{\text {water }}}{V_{\text {concrete }}}=\frac{\frac{w_{a}-w_{d}}{\rho_{\text {water }}}}{\frac{w_{d}}{\rho_{\text {concrete }}}}=\frac{w_{a}-w_{d}}{w_{a}-w_{w}}
$$

The samples were dried at 40 and $105^{\circ} \mathrm{C}$ to estimate the capillary porosity and the total (capillary and gel) porosity respectively.

Gas Permeability. A gas permeability test was conducted on concrete cores ( $d=150 \mathrm{~mm}, h=50 \mathrm{~mm}$ ) according to the recommendation RILEM TC 116-PCD (1999) using a CEMBUREAU permeameter. After being saturated in water, the concrete specimens were dried at $40^{\circ} \mathrm{C}$ until a constant weight was obtained (mass change $<0.05$ wt $\%$ over $24 \mathrm{~h}$ ). Hereby the tested test specimens had a saturation degree of $42.0 \pm 0.69 \mathrm{wt} \%$. During the measurement, the concrete specimens were placed in the permeameter cells as such as the oxygen gas was prevented from leaking. The first gas pressure was set at 2 bar, and the flow rate was measured using the soap bubble flow meter when a steady-state regime was established (after about $30 \mathrm{~min}$ ). Subsequently, the measurement was repeated for gas pressures of 3 and 4 bar. The measurements were then redone for all concrete specimens after drying at $105^{\circ} \mathrm{C}$ (saturation degree is nihil). The gas permeability coefficient $\left(\mathrm{k}-\mathrm{m}^{2}\right)$ is calculated according to the following formula:

$$
k=\frac{2 \cdot P_{a} \cdot Q \cdot h \cdot \eta}{A \cdot\left(P^{2}-P_{a}^{2}\right)}
$$

with $P_{a}\left(101,300 \mathrm{~N} / \mathrm{m}^{2}\right)$ the atmospheric pressure, $Q\left(\mathrm{~m}^{3} / \mathrm{s}\right)$ the measured flow rate, $h(0.05 \mathrm{~m})$ the specimen height, $A$ $\left(\pi \cdot(0.075 \mathrm{~m})^{2}\right)$ the cross-sectional area, $\eta\left(2.02 \cdot 10^{-5} \mathrm{~N} \cdot \mathrm{s} / \mathrm{m}^{2}\right)$ the dynamic viscosity of oxygen gas, and $P\left(\mathrm{~N} / \mathrm{m}^{2}\right)$ the applied pressure.

Carbonation. For an accelerated carbonation test, concrete cubes $\left(100 \times 100 \times 100 \mathrm{~mm}^{3}\right)$ were placed in a climate chamber $\left(20 \pm 2{ }^{\circ} \mathrm{C}, \mathrm{RH} 60 \pm 5 \%, 10 \% \mathrm{CO}_{2}\right)$ after 26 days of curing. Five surfaces of each concrete cube were coated to ensure a unidirectional $\mathrm{CO}_{2}$ ingress. The carbonation ingress was measured with phenolphthalein after every 28 days exposure to the high $\mathrm{CO}_{2}$ concentration.

Chloride Ingress. The resistance against the ingress of chlorides was evaluated by a CTH test, described in NT Build 492
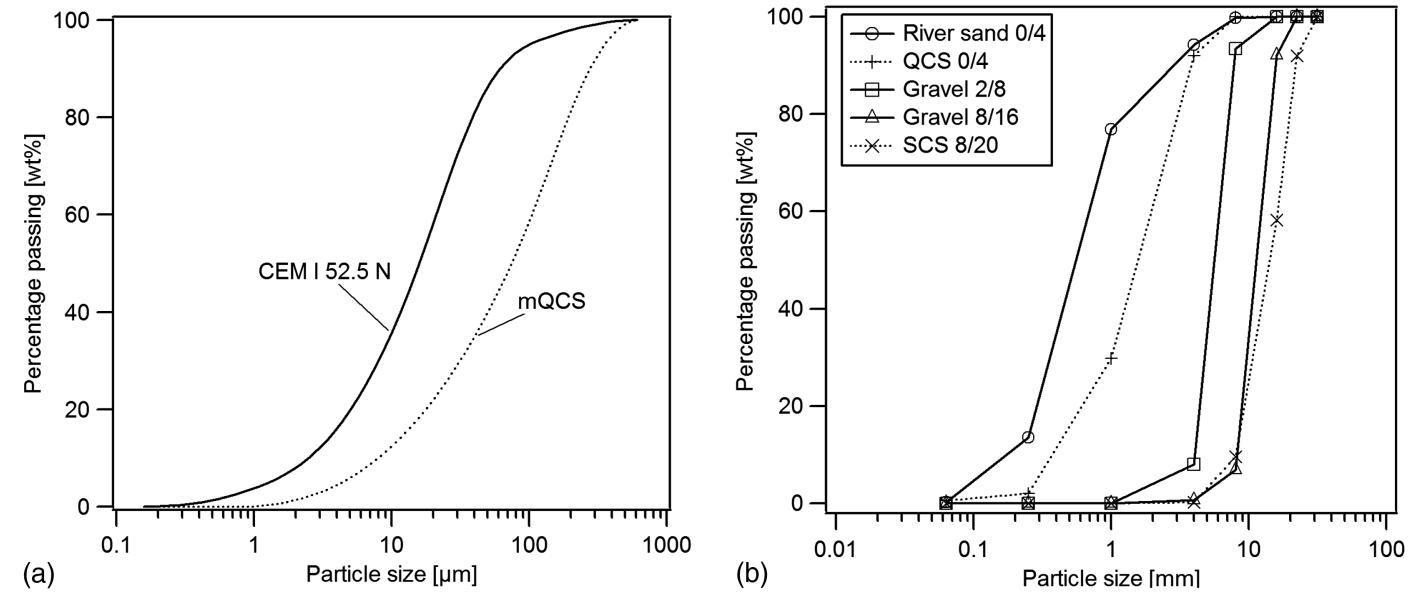

Fig. 2. Particle size distributions of the used materials determined by laser diffraction (a) or sieving (b) 
(1999). An external electrical potential applied axially across the specimen (drilled core with $d=100 \mathrm{~mm} h=50 \mathrm{~mm}$ ) forces chloride ions outside to migrate into the specimen. After a certain test duration (mostly $24 \mathrm{~h}$ ), a silver nitrate solution is sprayed on to freshly split sections, and the chloride penetration depth $\left(x_{d}-\mathrm{mm}\right)$ is measured. From these results a nonsteady-state migration coefficient $\left(D-10^{-12} \mathrm{~m}^{2} / \mathrm{s}\right)$ can be calculated:

$$
D=\frac{0.0239 \cdot(273+T) \cdot L}{(U-2) \cdot t}\left[x_{d}-0.0238 \sqrt{\frac{(273+T) \cdot L \cdot x_{d}}{U-2}}\right]
$$

with $U(V)$ the absolute value of the applied voltage, $T\left({ }^{\circ} \mathrm{C}\right)$ the average value of the initial and final temperatures in the anolyte solution, $L(\mathrm{~mm})$ the thickness of the specimen, and $t(\mathrm{~h})$ the test duration.

Freeze-Thaw Attack with Deicing Agents. The resistance against freeze-thaw attack with deicing agents was tested according to appendix D of NBN EN 1339 (NBN 2003). A concrete test specimen (drilled core $d=100 \mathrm{~mm} h=50 \mathrm{~mm}$ ) with a salt solution $(\mathrm{NaCl}, 3 \%)$ on top was subjected to 28 freeze-thaw cycles. After every 7 cycles, the scaled material was collected, dried for at least $24 \mathrm{~h}$ at $105 \pm 5^{\circ} \mathrm{C}$, and weighed.

\section{Statistical Analysis}

The software package SPSS Statistics was used for statistical analysis of the results. Analysis of variance (ANOVA) was used for comparison of the different mixtures. The Tukey and Dunnett method were applied for post hoc testing when equal variances are respectively assumed or not assumed. A significance level of 0.05 was used for all tests.

\section{Results}

\section{Copper Slag as Cement Replacement}

\section{Isothermal Calorimetry of Cement Pastes}

In Fig. 3, the heat production rate and cumulative heat production per gram of powder of cement pastes with varying mQCS content are presented. It is seen that both the maximum of the heat production rate and the cumulative heat production decrease with increasing mQCS content. It can also be observed that the maximum of the heat production rate moves further in time when more
CEM I $52.5 \mathrm{~N}$ is replaced by mQCS. To estimate the possible contribution of the mQCS to the heat production, the heat production rate and cumulative heat production per gram of CEM I $52.5 \mathrm{~N}$ are presented in Fig. 4. It is seen that the maximum values of the heat production rate are similar for all mixes, but the maximum moves further in time with increasing mQCS content. It is also observed that the cumulative hydration heat of the cement pastes with mQCS increase more compared with the reference mixture without mQCS.

\section{Compressive Strength of Mortars}

The compressive strength of mortars with increasing mQCS content to replace CEM I $52.5 \mathrm{~N}$ are presented in Table 4. Although the compressive strength test after 7 days indicated that the addition of $20 \mathrm{wt} \% \mathrm{mQCS}$ seems beneficial and results in a higher strength resistance compared with the reference, the reference mortar is the strongest after a curing period of 28 days. Except for the good result after 7 days for $20 \mathrm{wt} \% \mathrm{mQCS}$ addition, it can be observed that the compressive strength decreases with increasing mQCS content, for both curing times of 7 and 28 days.

\section{Copper Slag as Aggregate Replacement}

\section{Compressive Strength of Mortars}

Mortars with increasing QCS content in replacement of standard sand were tested for their compressive strength, and the results are presented in Table 4. For all mortar samples with QCS, the compressive strength after 7 days of curing is comparable for the different amounts of copper slag, although some results have significant differences between the mean values (Table 4). Compared with the reference mortar, all results for the copper slag mixtures are significantly higher. For the tests after a curing period of 28 days, the compressive strength results are similar for the reference mortar and the mortars with QCS, but again results might differ significantly. The mortars with 40 and $60 \mathrm{vol} \%$ QCS give the best results after 28 days, whereas the mortar with 100 vol\% QCS has the lowest strength, although not significantly different from the reference mortar.

\section{Compressive Strength of Concrete}

The results of the compressive strength tests on concrete with varying copper slag contents are presented in Table 5. For the mixtures with 20 vol\% copper slag (QCS-20 or SCS-20), the results are comparable for all curing ages (no significant differences). For the mixtures with 40 vol\% copper slag (QCS-40 and SCS-40),
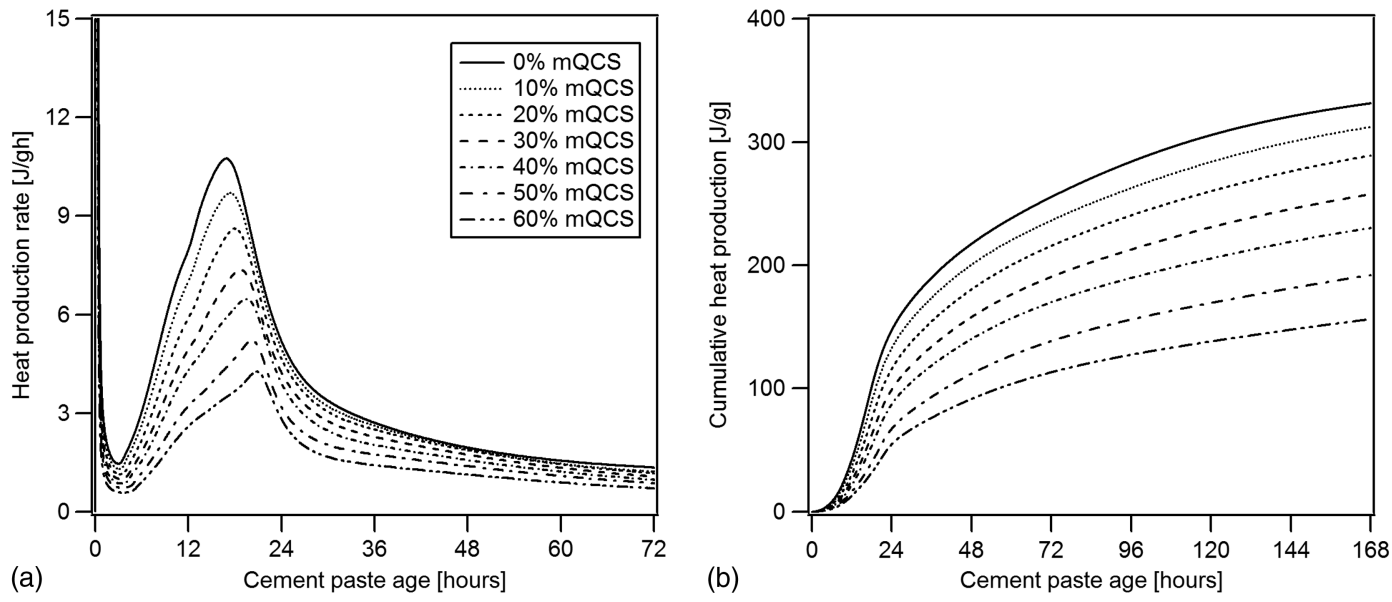

Fig. 3. Heat production rate (a); cumulative heat production (b) per gram of powder (both CEM I $52.5 \mathrm{~N}$ and mQCS) with varying mQCS contents 

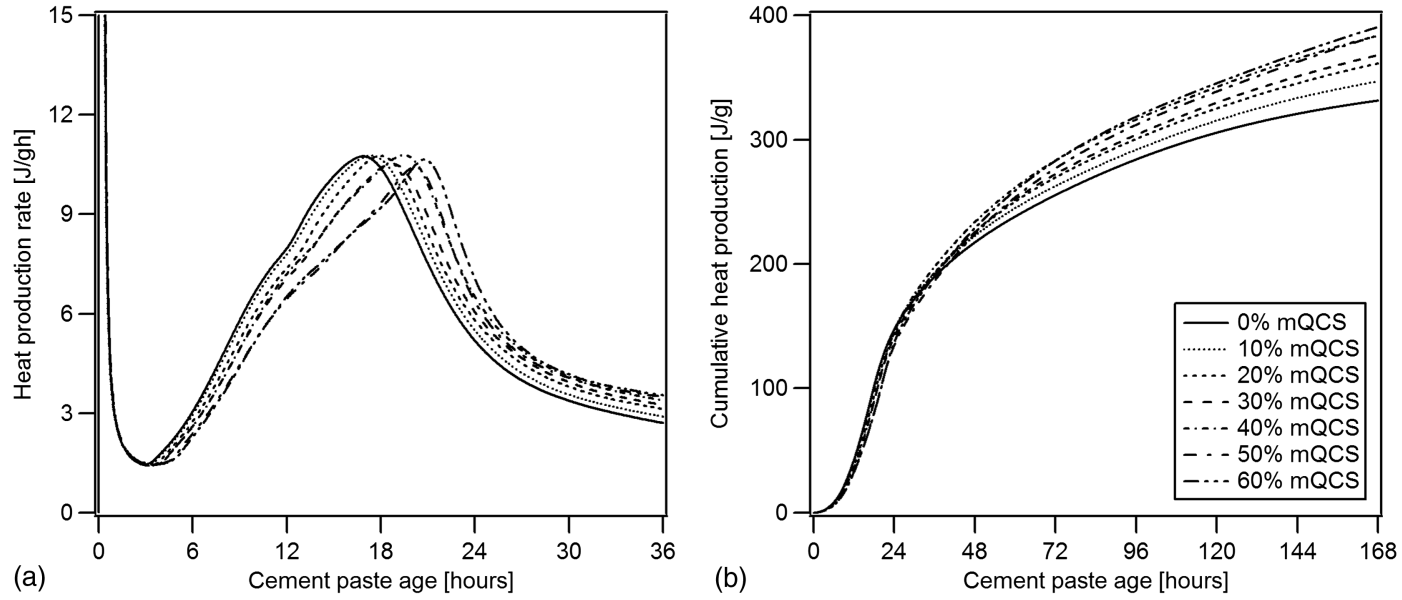

Fig. 4. Heat production rate (a); cumulative heat production (b) per gram of CEM I $52.5 \mathrm{~N}$ with varying mQCS contents

Table 4. Average Results of the Compressive Strength Tests $\left(\mathrm{N} / \mathrm{mm}^{2}\right)$ on Mortar Samples with Copper Slag as Cement (mQCS) or Sand (QCS) Replacement

\begin{tabular}{lll}
\hline $\begin{array}{l}\text { Amount and type } \\
\text { of copper slag }\end{array}$ & \multicolumn{1}{c}{7 days } & \multicolumn{1}{c}{28 days } \\
\hline Reference mortar & $31.5(0.90)$ & $61.5(0.92)^{\mathrm{D}, \mathrm{E}}$ \\
20wt\% mQCS & $36.8(0.51)$ & $44.7(0.49)$ \\
40wt\% mQCS & $26.1(0.17)$ & $34.3(0.25)$ \\
60wt\% mQCS & $13.9(0.10)$ & $17.2(0.27)$ \\
20vol\% QCS & $54.2(0.66)^{\mathrm{A}}$ & $63.4(0.66)^{\mathrm{E}, \mathrm{F}}$ \\
40vol\% QCS & $50.3(1.08)^{\mathrm{B}, \mathrm{C}}$ & $66.9(0.84)^{\mathrm{G}}$ \\
60vol\% QCS & $53.3(0.40)^{\mathrm{A}, \mathrm{B}}$ & $65.3(0.44)^{\mathrm{F}, \mathrm{G}}$ \\
80vol\% QCS & $52.7(0.25)^{\mathrm{A}, \mathrm{B}}$ & $62.7(0.64)^{\mathrm{E}, \mathrm{F}}$ \\
100vol\% QCS & $48.4(0.70)^{\mathrm{C}}$ & $58.2(0.82)^{\mathrm{D}}$ \\
\hline
\end{tabular}

Note: A capital superscript indicates the groups for which the mean values do not differ significantly; standard errors on the mean values are added between parentheses.

the results are only comparable after 28 and 84 days of curing, and the compressive strength of SCS-40 is significantly higher after 2 and 7 days of curing. Compared with the reference mixture, the results for concrete with $20 \mathrm{vol} \%$ and $40 \mathrm{vol} \%$ copper slag are respectively similar or higher (not in the case of QCS-40 after 2 and 7 days curing). Thus, from the compressive strength tests on concrete it can be concluded that the use of copper slag as aggregate results in comparable or even better results.

\section{Durability of Concrete}

The durability of concrete with copper slag as aggregate replacement was studied by testing several parameters, of which the results are presented in Table 5. Regarding durability the ingress of aggressive substances is an important issue. Important concrete characteristics regarding the ability of these substances to penetrate into concrete are its porosity and gas permeability. Looking at the results of the open porosity, the effect caused by the copper slag seems to be acceptable. The capillary porosity of QCS-20 and SCS-40 is comparable with the reference mixture, whereas the capillary porosity of SCS-20 and QCS-40 is respectively significantly higher or lower. For the total porosity, there is no significant difference for QCS-20 and QCS-40, which is also true for QCS-40, SCS-40, and the reference mixture. Again the total porosity of SCS-20 is significantly the highest. Nonetheless, the differences with the reference mixture seem minimal for all mixtures. The gas permeability is for all mixtures with copper slag lower compared with the reference, and this for all pressures and both drying temperatures. This improvement is, however, only significant for mixtures SCS-20 and SCS-40 after being dried at $105^{\circ} \mathrm{C}$. After drying at $40^{\circ} \mathrm{C}$, the reduction is significant for SCS-20 and SCS-40 for an applied pressure of 3 bar, for SCS-40 also at 4 bar.

Both the reference concrete and the mixtures with copper slag were subjected to a high $\mathrm{CO}_{2}$ concentration (10\%). All mixtures showed negligible carbonation up to 84 days. For the reference concrete and SCS-40, the first limited carbonation was observed after 84 days of exposure. For the other mixtures with copper slag, limited carbonation was measured after the first 28 days of carbonation. The ingress occurred locally, explaining the high variability. For example, where carbonation was measured after 28 and 56 days for QCS-20, no carbonation was measured after 84 days for the same mixture on different samples.

The migration of chlorides into concrete was tested by a CTH test. The chloride migration coefficient was for all mixtures with copper slag lower compared with the reference mixture. Except for QCS-20, this improvement was also significant.

Different surfaces (casted, sawn, and troweled) of most mixtures were tested for the resistance against freeze-thaw attack with deicing agents. The results of SCS-20 are not available as the test specimens were destroyed because of a technical defect, and the same concrete batch could not be tested again. The technical defect also made it impossible to have the results after 28 cycles for SCS40. The results presented in Table 5 clearly show that the resistance against freeze-thaw attack with deicing agents is worse for concrete with copper slag aggregates compared with the reference concrete. Although the effect of testing different surfaces is rather limited for the reference mixture, there is a higher variability for the mixtures with copper slag. However, there is no surface type showing consequently a better or worse performance for the different amounts and types of copper slag addition.

\section{Discussion}

\section{Copper Slag as Cement Replacement}

From the results obtained within this study, it can be concluded that the contribution of ground copper slag to the hydration degree of a cement paste is negligible. The hydration heat reduces with increasing mQCS content when plotted per gram of powder because of a decreasing cement content. The increase of the hydration heat when presented per gram of CEM I $52.5 \mathrm{~N}$ is probably caused by the 
Table 5. Results of Compressive Strength and Durability Tests on Concrete Containing Copper Slag

\begin{tabular}{|c|c|c|c|c|c|}
\hline Tested parameter & $\mathrm{CS}-0$ & QCS-20 & QCS-40 & SCS-20 & SCS-40 \\
\hline \multicolumn{6}{|l|}{ Fresh properties } \\
\hline Slump (mm) & 60 & 50 & 20 & 40 & 50 \\
\hline Air content $(\%)$ & 2.8 & 2.2 & 1.2 & 2.4 & 2.0 \\
\hline \multicolumn{6}{|l|}{ Compressive strength $\left(\mathrm{N} / \mathrm{mm}^{2}\right)$} \\
\hline 2 days & $34.7(0.31)^{\mathrm{a}}$ & $33.6(0.26)^{\mathrm{A}, \mathrm{B}}$ & $33.7(0.15)^{\mathrm{a}}$ & $32.2(0.48)^{\mathrm{b}}$ & $40.4(0.25)$ \\
\hline 7 days & $49.3(0.88)^{\mathrm{C}, \mathrm{D}}$ & $48.2(0.18)^{\mathrm{C}}$ & $51.8(0.78)^{\mathrm{D}}$ & $47.9(0.73)^{\mathrm{C}}$ & $56.2(0.47)$ \\
\hline 28 days & $57.0(0.98)^{\mathrm{E}}$ & $57.7(1.16)^{\mathrm{E}}$ & $63.7(1.49)^{\mathrm{F}}$ & $59.2(0.23)^{\mathrm{E}}$ & $65.6(0.31)^{\mathrm{F}}$ \\
\hline 84 days & $63.9(1.14)^{\mathrm{G}, \mathrm{H}}$ & $59.9(1.61)^{\mathrm{G}}$ & $69.3(1.61)^{\mathrm{H}}$ & $64.0(1.47)^{\mathrm{G}, \mathrm{H}}$ & $69.0(3.11)^{\mathrm{H}}$ \\
\hline \multicolumn{6}{|l|}{ Open porosity (vol\%) } \\
\hline Capillary porosity $\left(40^{\circ} \mathrm{C}\right)$ & $7.5(0.12)^{\mathrm{I}}$ & $7.9(0.15)^{\mathrm{I}}$ & $6.9(0.05)$ & $8.9(0.20)$ & $8.1(0.16)^{\mathrm{I}}$ \\
\hline Total porosity $\left(105^{\circ} \mathrm{C}\right)$ & $12.6(0.13)^{\mathrm{K}}$ & $11.9(0.08)^{\mathrm{J}}$ & $12.3(0.08)^{\mathrm{J}, \mathrm{K}}$ & $13.6(0.14)$ & $12.6(0.16)^{\mathrm{K}}$ \\
\hline Gel porosity $\left(105-40^{\circ} \mathrm{C}\right)$ & $5.1(0.16)^{\mathrm{M}, \mathrm{N}}$ & $4.0(0.13)^{\mathrm{L}}$ & $5.5(0.12)^{\mathrm{N}}$ & $4.7(0.15)^{\mathrm{M}}$ & $4.5(0.16)^{\mathrm{L}, \mathrm{M}}$ \\
\hline \multicolumn{6}{|c|}{ Gas permeability coefficient $\left(10^{-17} \mathrm{~m}^{2}\right)$-after drying at $40^{\circ} \mathrm{C}$} \\
\hline 2 bar & $6.7(0.44)^{\mathrm{O}}$ & $5.9(0.29)^{\mathrm{O}}$ & $5.5(0.61)^{\mathrm{O}}$ & $5.2(0.25)^{\mathrm{O}}$ & $5.1(0.08)^{\mathrm{O}}$ \\
\hline 3 bar & $4.5(0.29)^{\mathrm{P}}$ & $3.9(0.16)^{\mathrm{P}, \mathrm{Q}}$ & $3.5(0.38)^{\mathrm{P}, \mathrm{Q}}$ & $3.4(0.15)^{\mathrm{Q}}$ & $3.3(0.07)^{\mathrm{Q}}$ \\
\hline 4 bar & $4.1(0.27)^{\mathrm{R}}$ & $3.5(0.13)^{R, S}$ & $3.1(0.31)^{\mathrm{R}, \mathrm{S}}$ & $3.2(0.15)^{\mathrm{R}, \mathrm{S}}$ & $3.1(0.06)^{\mathrm{S}}$ \\
\hline \multicolumn{6}{|c|}{ Gas permeability coefficient $\left(10^{-17} \mathrm{~m}^{2}\right)$-after drying at $105^{\circ} \mathrm{C}$} \\
\hline 2 bar & $43.3(2.39)^{\mathrm{T}}$ & $39.0(0.96)^{\mathrm{T}}$ & $37.4(1.32)^{\mathrm{T}}$ & $30.2(0.94)^{\mathrm{U}}$ & $29.9(0.31)^{\mathrm{U}}$ \\
\hline 3 bar & $28.7(1.47)^{\mathrm{V}}$ & $25.5(0.67)^{\mathrm{V}}$ & $24.3(0.89)^{\mathrm{V}}$ & $19.8(0.64)^{\mathrm{W}}$ & $19.4(0.24)^{\mathrm{W}}$ \\
\hline 4 bar & $24.5(1.27)^{\mathrm{X}}$ & $21.2(0.62)^{\mathrm{X}}$ & $20.0(0.75)^{X}$ & $16.6(0.53)^{\mathrm{Y}}$ & $16.1(0.23)^{\mathrm{Y}}$ \\
\hline \multicolumn{6}{|l|}{ Carbonation depth (mm) } \\
\hline 28 days exposure & $-^{\mathrm{a}}$ & $0.76(0.17)$ & $0.30(0.08)$ & $0.06(0.04)$ & $-^{\mathrm{a}}$ \\
\hline 56 days exposure & $-^{\mathrm{a}}$ & $0.12(0.08)$ & $0.18(0.13)$ & $0.12(0.07)$ & $-^{\mathrm{a}}$ \\
\hline 84 days exposure & $0.24(0.09)$ & $-^{\mathrm{a}}$ & $0.52(0.16)$ & - $^{\mathrm{a}}$ & $0.24(0.08)$ \\
\hline \multicolumn{6}{|c|}{ Chloride migration coefficient $\left(10^{-12} \mathrm{~m}^{2} / \mathrm{s}\right)$} \\
\hline & $13.0(1.0)^{\mathrm{Z}}$ & $12.5(1.6)^{\mathrm{Z}}$ & $9.3(1.1)$ & $11.1(0.6)^{\mathrm{AA}}$ & $11.1(0.9)^{\mathrm{AA}}$ \\
\hline \multicolumn{6}{|c|}{ Scaled material due to freeze-thaw attack with deicing agents-casting surface $\left(\mathrm{kg} / \mathrm{m}^{2}\right)$} \\
\hline 7 cycles & $0.04(0.01)$ & $0.53(0.15)$ & $0.06(0.01)$ & $\mathrm{n} / \mathrm{a}^{\mathrm{b}}$ & $0.02(0.01)$ \\
\hline 14 cycles & $0.34(0.10)$ & $1.41(0.02)$ & $0.15(0.04)$ & $\mathrm{n} / \mathrm{a}^{\mathrm{b}}$ & $0.44(0.10)$ \\
\hline 21 cycles & $0.70(0.16)$ & $2.03(0.07)$ & $0.42(0.12)$ & $\mathrm{n} / \mathrm{a}^{\mathrm{b}}$ & $1.24(0.20)$ \\
\hline 28 cycles & $1.14(0.24)$ & $2.78(0.14)$ & $\mathrm{n} / \mathrm{a}^{\mathrm{b}}$ & $\mathrm{n} / \mathrm{a}^{\mathrm{b}}$ & $2.13(0.25)$ \\
\hline \multicolumn{6}{|c|}{ Scaled material due to freeze-thaw attack with deicing agents-sawn surface $\left(\mathrm{kg} / \mathrm{m}^{2}\right)$} \\
\hline 7 cycles & $0.17(0.23)$ & $0.11(0.02)$ & $0.24(0.03)$ & $\mathrm{n} / \mathrm{a}^{\mathrm{b}}$ & $0.17(0.03)$ \\
\hline 14 cycles & $0.34(0.05)$ & $0.34(0.03)$ & $0.62(0.05)$ & $\mathrm{n} / \mathrm{a}^{\mathrm{b}}$ & $0.63(0.06)$ \\
\hline 21 cycles & $0.63(0.13)$ & $0.90(0.09)$ & $1.08(0.09)$ & $\mathrm{n} / \mathrm{a}^{\mathrm{b}}$ & $1.23(0.09)$ \\
\hline 28 cycles & $1.04(0.23)$ & $1.63(0.20)$ & $\mathrm{n} / \mathrm{a}^{\mathrm{b}}$ & $\mathrm{n} / \mathrm{a}^{\mathrm{b}}$ & $1.85(0.16)$ \\
\hline \multicolumn{6}{|c|}{ Scaled material due to freeze-thaw attack with deicing agents-troweled surface $\left(\mathrm{kg} / \mathrm{m}^{2}\right)$} \\
\hline 7 cycles & $0.45(0.06)$ & $0.07(0.01)$ & $0.84(0.07)$ & $\mathrm{n} / \mathrm{a}^{\mathrm{b}}$ & $0.65(0.12)$ \\
\hline 14 cycles & $0.70(0.11)$ & $0.63(0.07)$ & $1.88(0.08)$ & $\mathrm{n} / \mathrm{a}^{\mathrm{b}}$ & $1.60(0.15)$ \\
\hline 21 cycles & $0.85(0.14)$ & $1.56(0.10)$ & $2.54(0.07)$ & $\mathrm{n} / \mathrm{a}^{\mathrm{b}}$ & $2.47(0.37)$ \\
\hline 28 cycles & $1.08(0.19)$ & $2.24(0.14)$ & $\mathrm{n} / \mathrm{a}^{\mathrm{b}}$ & $\mathrm{n} / \mathrm{a}^{\mathrm{b}}$ & $3.79(0.50)$ \\
\hline
\end{tabular}

Note: A capital superscript indicates the groups for which the mean values do not differ significantly (for the results of the compressive strength, open porosity, gas permeability, and chloride migration). Standard errors on the mean values are added between parentheses.

${ }^{\mathrm{a}}$ No carbonation observed.

${ }^{\mathrm{b}}$ Because of a technical defect, the test specimens were destroyed, and the same mixture could not be tested again.

increase of the water to cement ratio, as cement is replaced by an almost inert powder. The higher the water to cement ratio, the more water will be available for hydration, resulting in a higher ultimate hydration degree $\alpha_{u}$, which can be calculated according to the following formula (Mills 1966) cited in Baert (2009):

$$
\alpha_{u}=\frac{1.031 \cdot W / C}{0.194+W / C}
$$

For all mixtures, the ultimate hydration degrees were calculated using their water to cement ratio and the above mentioned formula. For comparison, the hydration degree after 7 days was calculated as the ratio of the total measured heat to the potential heat of the cement. The latter was calculated using the mineralogical composition of the cement (Table 2) and the potential heat release of the different clinker minerals: 500, 260, 1,673, and $42 \mathrm{~J} / \mathrm{g}$ for alite, belite, aluminate, and ferrite respectively. It was found that the calculated hydration degrees after 7 days of hydration are comparable with the calculated ultimate hydration degrees (Fig. 5). Comparable hydration degrees after 7 days were obtained in Baert (2009), when the effect of the water to cement ratio on the heat release of ordinary Portland cement pastes was studied. This confirms the presumption that the measured increase of the hydration heat per gram of cement can be attributed to the variation in water to cement ratio, and the effect of the copper slag is nihil. The delay of the main hydration peak can be explained by the set-inhibiting properties of heavy metals in copper slag (Zain et al. 2004), see Table 1. The reduction in compressive strength with increasing copper slag content is explained by the lower cement content of the mixtures.

Looking into the literature, it is seen that most researchers use much lower replacement levels of up to $15 \mathrm{wt} \%$ (Al-Jabri et al. 2006; Shi et al. 2008; Taha et al. 2004; Tixier et al. 1997; Zain et al. 2004). Their conclusion is that the effect of using copper slag 


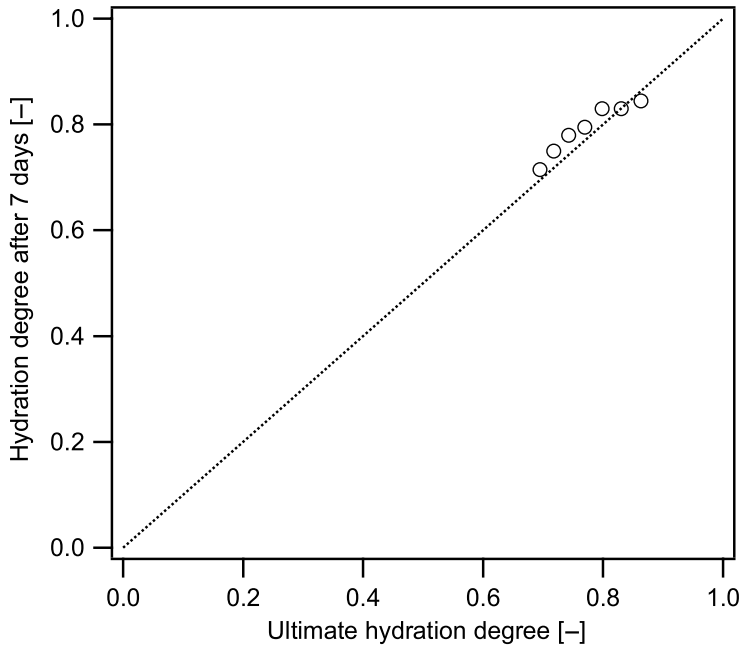

Fig. 5. Comparison of the calculated ultimate hydration degree and hydration degree based on the measured hydration heat after 7 days for cement pastes with varying mQCS content

on compressive strength is limited, and only in some cases small improvements were noticed. Some researchers used activators such as cement by-pass dust and/or lime, which had no effect (Al-Jabri et al. 2006) or only a limited effect (Taha et al. 2004). In Tixier et al. (1997), a positive effect on the compressive strength from adding copper slag was noticed. This copper slag was well crystallized, and the fineness of the copper slag was comparable with the one of cement, which is not the case for the copper slag mQCS used in this study (Fig. 2). In further research, it might thus be interesting to start from the SCS instead of QCS, and higher finenesses should be aimed for.

Finally, it is worth mentioning that the replacement of cement by copper slag results in a better resistance regarding sulphate attack (Najimi et al. 2011). The replacement with copper slag up to $15 \%$ led to more than $50 \%$ decrease in sulphate expansion, accompanied with less strength degradation. Microstructure studies showed that ettringite, present in the control samples, was absent in the samples with copper slag. The results were explained as follows (Najimi et al. 2011): a reduced $C_{3} A$ content because of the replacement with copper slag, a reduction of soluble calcium hydroxide (if copper slag would show a mediocre pozzolanic reactivity), or a less permeable microstructure from the copper slag addition.

\section{Copper Slag as Aggregate Replacement}

From the compressive strength test results, it was concluded that the replacement of sand by copper slag had no significant effect on the strength performance of the mortars. As the compressive strength of mortars with $40 \mathrm{vol} \%$, QCS was the highest, and literature suggests replacement levels of about 40-50\% (Al-Jabri et al. 2011, 2009a; Shi et al. 2008); the replacement levels for concrete were chosen to be 20 and $40 \mathrm{vol} \%$, for both the fine fraction (with QCS) and the coarse fraction (with SCS). Regarding the compressive strength of this concrete compared with the reference, it was concluded that the results were similar or even better. Similar or slightly improved compressive strengths were expected from literature (Al-Jabri et al. 2011; Shi et al. 2008; Wu et al. 2010a, b) and are related to the physical properties of the copper slag. Copper slag has a better compressibility than natural aggregates, partially relieving the stress concentration, if natural sand is still the dominant fine aggregate holding the concrete matrix together. Also the angular sharp edges of the copper slag can improve the cohesion of the concrete matrix, although the glassy surface of the copper slag can have a negative effect on the cohesion. Furthermore copper slag as aggregate replacement can have a negative effect on the compressive strength because of their low water absorption, leaving excess water as discussed later in this paper.

The performance of the concrete with copper slag was compared with the reference concrete by means of durability indices (DI; Kaid et al. 2009). These indices are formulated as such that values higher than 1 indicate the copper slag concrete performs better than the reference concrete. The results are presented in Fig. 6. It was found that the effect of aggregate replacement levels of 20 and $40 \mathrm{vol} \%$ was limited regarding the open porosity and gas permeability. For SCS20 and SCS-40, the gas permeability was even reduced compared with the reference. Regarding carbonation and chloride migration, the performance of the concrete with copper slag is comparable with the one of the reference concrete. However, in the test for freeze-thaw attack with deicing agents, the concretes with copper slag performed worse compared with the reference, and the surface scaling after 28 standardized freeze-thaw cycles increased significantly. Depending on the surface and the mixture the surface scaling increased by 57 to $252 \%$ because of the addition of copper slag. As required by NBN EN 1339 (NBN 2003), the amount of scaled material should not exceed the limit of $1 \mathrm{~kg} / \mathrm{m}^{2}$. In Table 5 it is seen that even the reference mixture is slightly exceeding the limit. The performance regarding freeze-thaw attack with deicing agents is strongly related to the air content of fresh concrete. As can be seen in Table 5, the air contents are rather low for both the reference and copper slag concrete. The European standard NBN EN 206-1 (NBN 2001b) and the Belgian standard NBN B 15-001 (NBN 2004) require an air content of at least $4 \%$ for a nominal maximum aggregate size of $20 \mathrm{~mm}$. In the American standard, ACI 201.2 R (ACI 2008) requires even an air content of $6-7 \%$. It is thus advised to improve the resistance against freeze-thaw attack with deicing agents by means of, for example, air entraining agents.

An effect on strength and durability from the addition of copper slag was expected, as the low water absorption and glass-like smooth surface create a water excess and thus a risk for bleeding (Al-Jabri et al. 2009b; Shi et al. 2008; Wu et al. 2010a) since the water to cement ratio is kept constant. This excess water is water that is not absorbed by the aggregates and becomes available in the cement matrix that results in a higher content of voids, micro cracks, and capillary channels, especially when the substitution rate exceeds 20\% (Wu et al. 2010a). This has of course its consequences for the performance of the concrete. From the results reported in this paper, it was concluded that mainly the performance regarding freeze-thaw attack with deicing agents of the copper slag concrete was reduced compared with the reference concrete. In case of the copper slag concrete, it might thus not be only the air content of the fresh concrete that resulted in the inferior performance, but also the quality of the concrete surfaces is expected to be reduced because of an excess of water and thus a risk for bleeding and segregation (Shi et al. 2008). In order to compensate for this excess in water, less water could be added. Al-Jabri et al. (2009b) replaced sand by copper slag keeping the workability constant and adapting the water to cement ratio. They concluded that a $100 \%$ replacement of the sand by copper slag results in a water reduction of $22 \%$. In this study both the water to cement ratio (0.45) and amount of superplasticizer ( $2 \mathrm{ml} / \mathrm{kg}$ binder) of the copper slag concrete were kept constant. As observed in Table 5, the slump of the copper slag mixtures is rather low, although the risk for bleeding was observed. A detailed study on the water demand of the mixtures is required. The optimum should allow a sufficient slump of the concrete, without the risk for bleeding. 

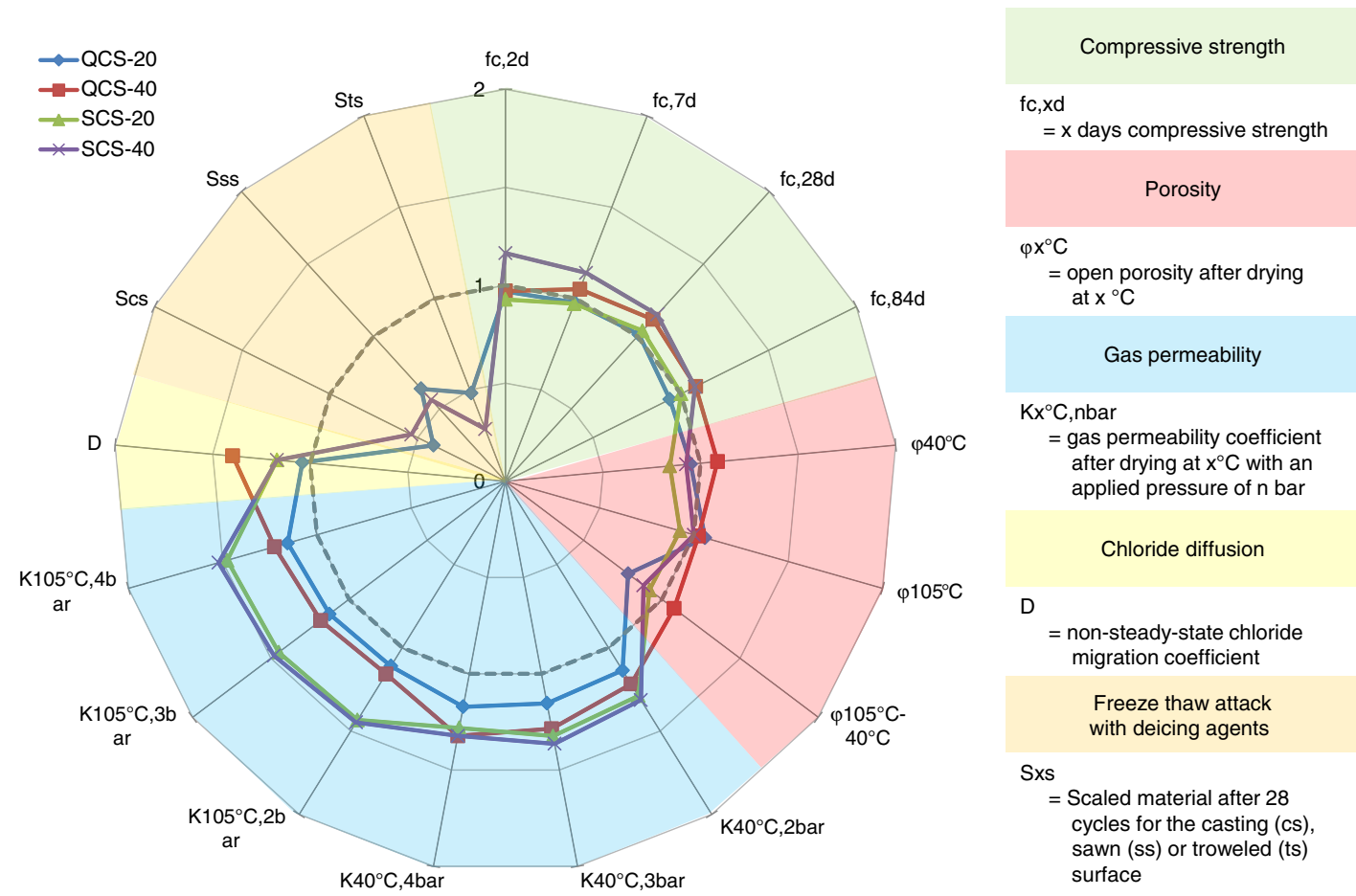

Fig. 6. Durability indices (dashes) to compare the performance of concrete with copper slag to the reference concrete

\section{Conclusions}

Copper slag is interesting as an iron source for the production of CRC. First of all, it is an industrial by-product that reduces the use of natural resources on the one hand and the waste production on the other hand. Secondly, it is already used as raw material in the cement production as an iron adjusting material, and the final destiny of CRC is to become a raw meal for cement production. The only question that remained was: how to use this material within concrete? From literature, it was concluded that there are two possibilities: as an alternative binder or as an aggregate. Both possibilities were tested for the copper slag available, and it was concluded that the use of copper slag as an alternative binder was of minor interest because no significant pozzolanic reaction was observed. The use of copper slag as aggregate replacement is, however, promising. The effects on the compressive strength, open porosity, gas permeability, resistance against carbonation, and chloride ingress seemed acceptable or even an improved performance of the concrete was observed. The latter can be related to the physical properties of the copper slag, having an improved compressibility and improved cohesion due to the angular sharp edges. Only the resistance to freeze-thaw attack with deicing agents was inferior. The performance in such an environment might however be improved by adapting the water content of the concrete or the addition of an air entrainer. The excess of water due to the lower water absorption of the copper slag was claimed to be the main parameter negatively affecting the performance of the concrete regarding freeze-thaw attack with deicing agents.

\section{Acknowledgments}

Financial support from the Institute for the Promotion of Innovation through Science and Technology in Flanders (IWT-Vlaanderen) and the Research Foundation Flanders (FWO) (Grant no. G087510 N) for this study is gratefully acknowledged.

\section{References}

ACI. (2008). "Guide to durable concrete." 201.2 R, ACI, Farmington Hills, MI.

Al-Jabri, K. S., Al-Saidy, A. H., and Taha, R. (2011). "Effect of copper slag as a fine aggregate on the properties of cement mortars and concrete." Constr. Build. Mater., 25(2), 933-938.

Al-Jabri, K. S., Hisada, M., Al-Oraimi, S. K., and Al-Saidy, A. H. (2009a). "Copper slag as sand replacement for high performance concrete." Cem. Concr. Compos., 31(7), 483-488.

Al-Jabri, K. S., Hisada, M., Al-Saidy, A. H., and Al-Oraimi, S. K. (2009b). "Performance of high strength concrete made with copper slag as a fine aggregate." Constr. Build. Mater., 23(6), 2132-2140.

Al-Jabri, K. S., Taha, R. A., Al-Hashmi, A., and Al-Harthy, A. S. (2006). "Effect of copper slag and cement by-pass dust addition on mechanical properties of concrete." Constr. Build. Mater., 20(5), 322-331.

Arab, H. B. (2006). "Aggregates from construction \& demolition waste in Europe." State of play-Providing essential materials for Europe, European Aggregates Association, Brussels, Belgium.

Baert, G. (2009). "Physico-chemical interactions in Portland cement(high volume) fly ash binders." Ph.D. thesis, Ghent Univ., Ghent.

De Belie, N., and Robeyst, N. (2007). "Recycling of construction materials." Environment-conscious construction materials and systems, State of the art report of TC 192-ECM, RILEM Rep. No. 37, N. Kashino, D. Van Gemert and K. Imamoto, eds., RILEM Publications S.A.R.L., Bagneux, 11-23.

De Schepper, M., De Buysser, K., Van Driessche, I., and De Belie, N. (2013). "The regeneration of cement out of completely recyclable concrete: Clinker production evaluation." Constr. Build. Mater., 38, 1001-1009.

De Schepper, M., Snellings, R., De Buysser, K., Van Driessche, I., and De Belie, N. (2014). "The hydration of cement regenerated from completely recyclable concrete." Constr. Build. Mater., 60(0), 33-41.

De Schutter, G. (1999). "Hydration and temperature development of concrete made with blast-furnace slag cement." Cem. Concr. Res., 29(1), 143-149.

Goñi, S., Lorenzo, M. P., and Sagrera, J. L. (1994). "Durability of hydrated Portland cement with copper slag addition in $\mathrm{NaCl}+\mathrm{Na} 2 \mathrm{SO} 4$ medium." Cem. Concr. Res., 24(8), 1403-1412. 
Gorai, B., and Jana, R. K. (2003). "Characteristics and utilisation of copper slag-A review." Resour. Conserv. Recycl., 39(4), 299-313.

Kaid, N., Cyr, M., Julien, S., and Khelafi, H. (2009). "Durability of concrete containing a natural pozzolan as defined by a performance-based approach." Constr. Build. Mater., 23(12), 3457-3467.

Khanzadi, M., and Behnood, A. (2009). "Mechanical properties of highstrength concrete incorporating copper slag as coarse aggregate." Constr. Build. Mater., 23(6), 2183-2188.

Kogel, J. E., Trivedi, N. C., and Barker, J. M. (2006). Industrial minerals and rocks, 7th Ed., Society for Mining, Metallurgy and Exploration, Englewood, CO.

Langer, W. H., Drew, L. J., and Sachs, J. S. (2004). "Aggregate and the environment: Production, construction, reclamation." American Geological Institute, Alexandria.

McDonough, W., and Braungart, M. (2002). Cradle to cradle: Remaking the way we make things, 1st Ed., North Point Press, New York.

Mills, R. H. (1966). "Factors influencing cessation of hydration in watercured cement pastes." Symp. on the Structure of Portland Cement Paste and Concrete, Highway Research Board Special Rep. 90, Highway Research Board, Washington, DC, 406-424.

Najimi, M., Sobhani, J., and Pourkhorshidi, A. R. (2011). "Durability of copper slag contained concrete exposed to sulfate attack." Constr. Build. Mater., 25(4), 1895-1905.

NBN. (1976). "Testing of building materials: Resistance to freezing: Water absorption by capillarity." B 05-201, NBN, Brussels, Belgium.

NBN. (2001a). "Testing hardened concrete-Part 1: Shape, dimensions and other requirements for specimens and moulds." EN 12390-1, NBN, Brussels, Belgium.

NBN. (2001b). "Concrete-Part 1: Specification, performance, production and conformity." EN 206-1, NBN, Brussels, Belgium.

NBN. (2003). "Concrete paving flags-Requirements and test methods." EN 1339, NBN, Brussels, Belgium.

NBN. (2004). "Supplement to NBN EN 206-1—concrete—specification, performance, production and confirmity." B 15-001, NBN, Brussels, Belgium.

NBN. (2005). "Methods of testing cement-Part 1: Determination of strength." EN 196-1, NBN, Brussels, Belgium.
NT Build 492. (1999). Concrete, mortar and cement-based repair materials: Chloride migration coefficient from non-steady state migration experiments.

RILEM TC 116-PCD. (1999). "Permeability of concrete as a criterion of its durability." Final report: Concrete durability—An approach towards performance testing Vol. 32, RILEM Publications SARL, Bagneux, France, 163-173.

Shi, C., Meyer, C., and Behnood, A. (2008). "Utilization of copper slag in cement and concrete." Resour. Conserv. Recycl., 52(10), 1115-1120.

Taha, R., Al-Rawas, A., Al-Jabri, K., Al-Harthy, A., Hassan, H., and Al-Oraimi, S. (2004). "An overview of waste materials recycling in the Sultanate of Oman." Resour. Conserv. Recycl., 41(4), 293-306.

Taha, R. A., Alnuaimi, A. S., Al-Jabri, K. S., and Al-Harthy, A. S. (2007), "Evaluation of controlled low strength materials containing industrial by-products." Build. Environ., 42(9), 3366-3372.

Tamura, M., Noguchi, T., and Tomosawa, F. (2004). "Cementitious wastefree-type completely recyclable concrete." Proc., RILEM Int. Symp. on Environment-Conscious Materials and Systems for Sustainable Development, N. Kashino and Y. Ohama, eds., RILEM Publications SARL, Bagneux, France, 61-71.

Thomas, B. S., Anoop, S., and Kumar, V. S. (2012). "Utilization of solid waste particles as aggregates in concrete." Procedia Eng., 38, 3789-3796.

Tixier, R., Devaguptapu, R., and Mobasher, B. (1997). "The effect of copper slag on the hydration and mechanical properties of cementitious mixtures." Cem. Concr. Res., 27(10), 1569-1580.

Wu, W., Zhang, W., and Ma, G. (2010a). "Mechanical properties of copper slag reinforced concrete under dynamic compression." Constr. Build. Mater., 24(6), 910-917.

Wu, W., Zhang, W., and Ma, G. (2010b). "Optimum content of copper slag as a fine aggregate in high strength concrete." Mater. Des., 31(6), 2878-2883.

Zain, M. F. M., Islam, M. N., Radin, S. S., and Yap, S. G. (2004). "Cementbased solidification for the safe disposal of blasted copper slag." Cem. Concr. Compos., 26(7), 845-851. 